\title{
КОМПЛЕКС ПРЕДПОЛЕВЫХ КОСМОГЕОЛОГИЧЕСКИХ МЕТОДОВ ПОИСКОВ ПОЛЕЗНЫХ ИСКОПАЕМЫХ
}

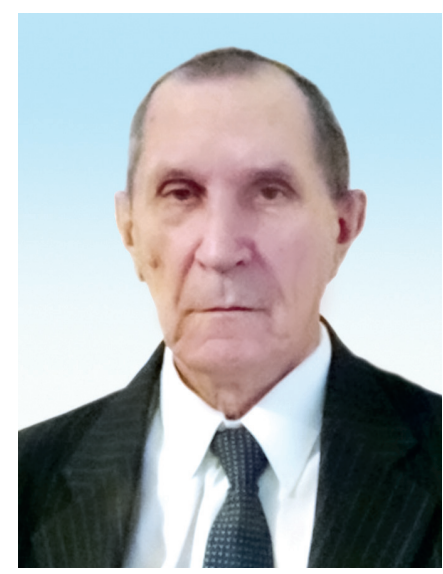

B.P. ТУМАНОВ кандидат геол.-мин. наук, главный геолог

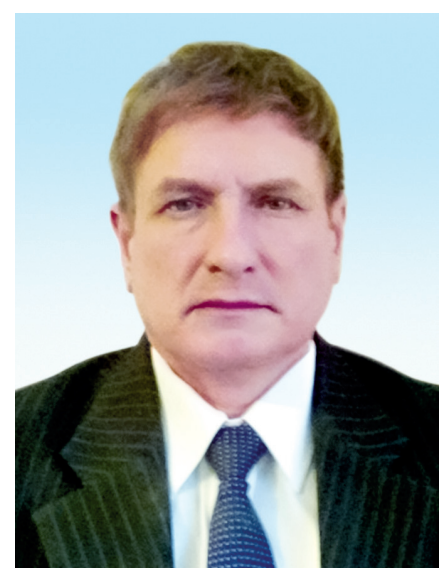

Р.Р. МУХАМЕДЯРОВ, директор

ООО «КОСМИЧЕСКИЕ ТЕХНОЛОГИИ»

Российская Федерация, 420107, г. Казань, Петербургская 50, стр. 5, офис 225

Комплекс предполевых космогеологических методов поисков полезных ископаемых предназначен для того, чтобы оперативно и как можно более полно осмысливать и выражать картографически всю геологическую информацию (наземную и дистанционную, предшественников и полученную вновь) на основе космических изображений в видимых и инфракрасных диапазонах. По результатам исследований обосновываются решения о выборе лицензионных участков, объемах дорогостоящих полевых работ, существенно сокращается стоимость поисков полезных ископаемых за счет своевременной отбраковки пустых территорий и оконтуривания вероятных залежей полезных ископаемых (нефоти, газа, подземных вод, гидротермальных источников энергии, твердых полезных ископаемых, при наличии геологических аналогов - с подсчетом локализованных ресурсов).

КЛЮЧЕВЫЕ СЛОВА: углеводороды, нефть, газ, подземные воды, геотермальные источники энергии, уран, алмазы, полиметаллы, геофизические поиски, тепловое излучение, Казахстан.

\section{ПАЙДАЛЫ ҚАЗБАЛАРДЫ ДАЛА АЛДЫНДАҒЫ ІЗДЕУДІҢ КОСМОГЕОЛОГИЯЛЫҚ ӘДІСТЕРІНІҢ КЕШЕНІ}

В.Р. ТУМАНОВ, кандидат геол.-мин. ғылымдар, бас геолог P.P. МҰХАМЕДЯРОВ, директор

«SPACE TECHNOLOGIES» ЖШC,

Ресей Федерациясы, 420107, Қазан қ., Петербургская 50, 5 корпус, 225 кеңсе

\footnotetext{
* Адрес для переписки. E-mail: geotech@list.ru
} 
Пайдалы қазбаларды іздеудің дала алдындағы космогеологиялық әдістерінің кешені көрінетін және инфрақызыл диапазондардағы ғарыштық суреттер негізінде барлық геологиялық ақпаратты (жердегі және шалғайдағы, алдыңғы және қайтадан алынған) тез және мүмкіндігінше тез және толық түсінуге және картографриялық түрде көрсетуге арналған. Жүргізілген зерттеулердің нәтижелері бойынша лицензиялық аумақтарды таңдау бойынша шешімдер, қымбат тұратын дала жұмыстарының көлемі негізделді, бос аумақтарды уақтылы қабылдамау және пайдалы қазбалардың болжамды кен орындарының шекарасын белгілеу есебінен пайдалы қазбаларды іздеуге кететін шығындар айтарлықтай төмендеді (жылы сенімді геологиялық аналогтардың болуы - жергілікті ресурстарды есептеумен).

ТҮЙІн СӨЗДЕР: көмірсутектер, мұнай, газ, жер асты сулары, геотермалдық энергия көздері, уран, алмаздар, полиметалдар, геофизикалық барлау, жылу радиациясы, Қазақстан.көмірсутектер, мұнай, газ, геофизикалық барлау, жылу радиациясы, Қазақстан.

\title{
COMPLEX OF PRE-FIELD COSMOGEOLOGICAL METHODS FOR MINERAL RESOURCES EXPLORATION
}

\author{
V.R. TUMANOV, candidate geol.-min. sciences, chief geologist \\ R.R. MUKHAMEDYAROV, director of "SPACE TECHNOLOGIES" LLC \\ "SPACE TECHNOLOGIES" LLC \\ 50, Petersburgskaya str., building 5, office 225, Kazan, 420107, Russian Federation
}

The complex of pre-field cosmogeological methods for exploring of minerals is designed to quickly and as fully as possible comprehend and express cartographically all geological information (ground and remote, predecessors and obtained again) based on space images in the visible and infrared ranges. Based on the research results, decisions on the choice of license areas, the volume of expensive field work are substantiated, the cost of exploration of minerals is significantly reduced due to the timely rejection of empty areas and delineation of probable deposits of minerals (oil, gas, groundwater, hydrothermal energy sources, solid minerals - in the presence of reliable geological analogues - with the calculation of localized resources).

KEY WORDS: hydrocarbons, oil, gas, groundwater, geothermal energy sources, uranium, diamonds, polymetals, geophysical prospecting, thermal radiation, Kazakhstan.

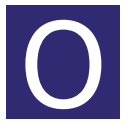

собенности и новизна технологий. Особенностью комплекса, позволяющего от картирования излучения с поверхности Земли перейти к глубинной цифровой модели поля теплового излучения и относительной водонасыщенности недр, является общепринятое в геофизике представление, что чем крупнее неоднородности по площади, тем глубже они расположены, но отображение их становится все более обобщенным. Пошагово усредняя данные, можно проследить положение границ между неоднородностями на глубину. В отношении поля теплового излучения идея метода принадлежит доктору технических наук, профессору Р.Д. Мухамедярову $[1,2]$. Эта идея была доведена до уровня технологии с созданием глубинной цифровой модели коллективом сотрудников ООО «Космические технологии» под руководством Р.Р. Мухамедярова, авторами программ математической обработки являются Р.Т. Маннанов и Д.Н. Заляев, методика геологической интерпретации цифровой модели поля теплового излучения Земли разработана В.Р. Тумановым [3], им же позднее [4,5] предложен параметр относительной водонасыщенности как отношение летнего теплового излучения к зимнему. В адаптации метода к условиям Казахстана важная роль принадлежит А.И. Дабаеву [6]. 
На рисунке 1 показана общая схема исследований на примере поисков месторождений углеводородного сырья. Взяв от поверхности и предшественников все полезное, мы переходим к сопоставлению данных с объемной моделью поля теплового излучения и водонасыщенности недр. Подобная схема проверена опытом целевой интерпретации космогеологических данных по более чем 20 проектам, нацеленным на поиски:

- Углеводородов;

- подземных вод;

- геотермальных источников энергии;

- инфильтрационных месторождений урана;

- месторождений алмазов;

- полиметаллических руд.

Площади работ могут варьировать в зависимости от изученности территорий от первых сотен тысяч до десятков км². Если целесообразно оценить минерагеническую область в сотни - десятки тысяч км², разрезы строятся сначала по сети $100 \times 100$ км (Ангола, Ливия), и с учетом результатов построений - по сети $10 \times 10$ км (Восточная пустыня Египта), а на перспективных участках размером в первые тысячи - сотни км ${ }^{2}-$ по сети $1 \times 1$ км $(0,5 \times 0,5$ км) с прогнозированием конкретных залежей полезных ископаемых.

Сбор данных предшественников осуществляется из всех доступных источников с их масштабированием в соответствии с заданной детальностью работ, как правило 1:100 000. Таким образом выявляются противоречия в построениях предшественников. Карты любого содержания (топографические, геологические, геофизические, иные тематические карты), привязанные в географической системе координат, копируются в графический редактор в виде отдельных электронных слоев. Это дает возможность наложения карт друг на друга в любых сочетаниях с заданной степенью полупрозрачности. Таким образом наглядно выявляются расхождения между геологическими контурами и это облегчает выбор из них границ, которые наиболее обоснованы и важны.

При дешифрировании сейсмических разрезов и физических полей выделяются только фактически наблюдаемые элементы, трассирование их считается правомочным на этапе обобщения. При таком подходе мы убеждаемся, что как в обнажениях, так и на сейсмических разрезах малоамплитудные разломы в осадочном покрове - это не одна ровная плоскость, а совокупность трещин и смещений, фрагментарно проявляющихся в слоях пород разного состава, преломляющихся по ним и в некоторых слоях не прослеживающихся, местами выраженных очень ярко. По рисунку и соотношению трещин удается понять кинематику смещений.

Проработав материалы предшественников, мы составляем карту современной геодиамики на основе изучения цифровой модели рельефа. Карта помогает наметить будущие пути исследований. На карте показываются геодинамические зоны с преобладающим неотектоническим режимом, характерными структурами второго порядка, линеаменты, отрисованные по цифровой модели рельефа. Карта может дополняться элементами интерпретации физических полей и сеткой более детально отдешифрированных линеаментов с космогеологической карты, речь о 
ИСХОДНЫЕ ДАННЫЕ

Данные предшественников

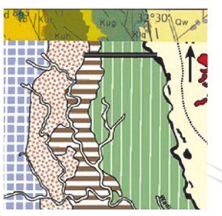

\section{PЕЗУЛIЫТАТЫ РАБОТ}

Схема геодинамики

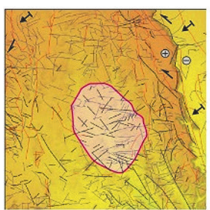

\section{ИЗУЧЕНИЕ ПОВЕРХНОСТИ}

Снимки Landsat
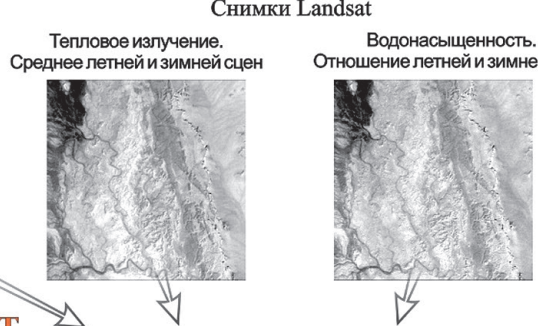

Космические изображения в Google Earth

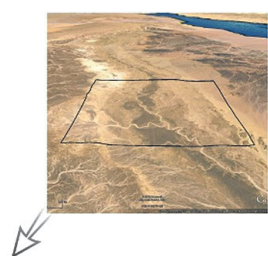

\section{КОСМОГЕОЛОГИЧЕСКАЯ ЭЛЕКТРОННАЯ КАРТА}

$\begin{array}{ll}\text { Линеаменты } & \text { Геологическая карта } \\ \text { в традиционном виде }\end{array}$ Геологическая карта врадиционном виде на фоне каналов Landsat

Стратиграфическая
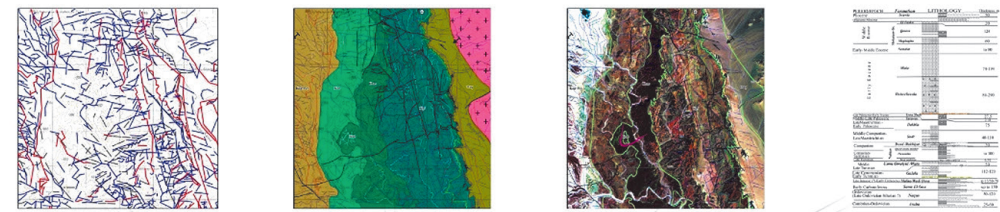

Содержание: рельеф, морфоструктуры, геодинамика, разломы, формации, складки, структурные элементы

$$
\triangle \text { ОБЪЕМНАЯ ЦИФРОВАЯ МОДЕЛЬ }
$$

Вертикальные разрезы

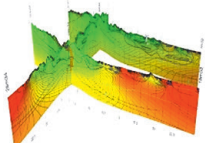

Поле теплового излучения

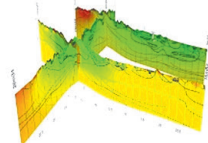

Bo

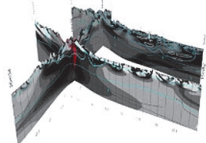

Блоково-ячеи Н структура
Субгоризонтальные срезы

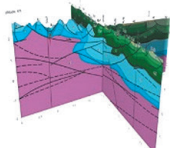

Геологическая 4 интерпретация КАРТА ПРОГНОЗОВ И РЕКОМЕНДАЦИЙ
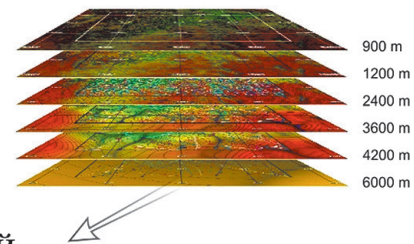

ВЕРТИКАЛЬНЫЙ РАЗРЕЗ

Рекомендуемые скважины

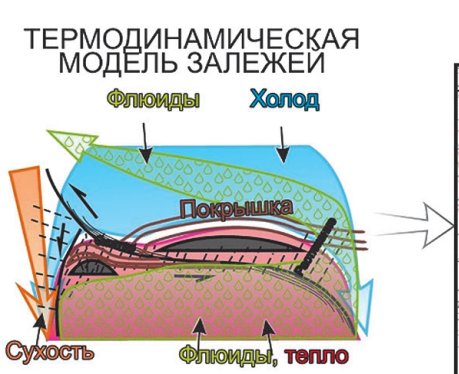

Poкомендуемыл скваманы
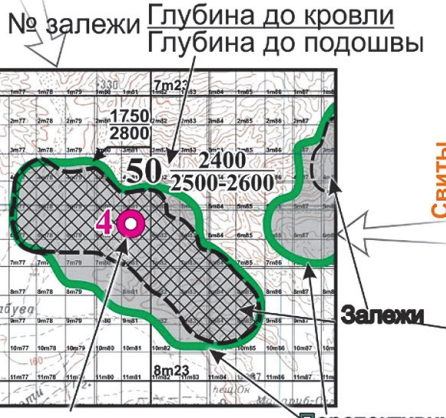

- $\stackrel{\infty}{\stackrel{0}{\kappa}} \propto$

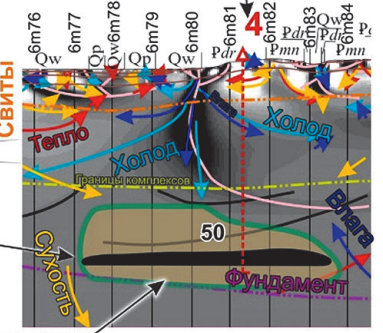

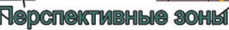

\begin{tabular}{|c|c|c|c|c|c|c|c|}
\hline $\begin{array}{c}\text { № } \\
\text { объекта }\end{array}$ & $\begin{array}{l}\text { Положение на карте } \\
\text { прогнозов, метки на } \\
\text { профнлях } 1 \times 1 \text { kм }\end{array}$ & $\begin{array}{l}\text { Глубина до } \\
\text { кровли, м }\end{array}$ & $\begin{array}{l}\text { Глубина до } \\
\text { подошвы, }\end{array}$ & Площадь, км² & Вмещающие породы, тип геологического разреза & $\begin{array}{l}\frac{\text { Предполагаемый }}{\text { тип ловушки }} \\
\text { Predicted trap type }\end{array}$ & $\begin{array}{l}\text { Перспективность } \\
\begin{array}{l}++ \\
++ \\
+- \\
+-\end{array}\end{array}$ \\
\hline 50 & $\begin{array}{l}3 \mathrm{~m} 77-3 \mathrm{~m} 80- \\
10 \mathrm{~m} 83-10 \mathrm{~m} 85\end{array}$ & 2400 & $2500-2600$ & 24.98 & 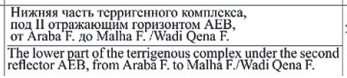 & $\begin{array}{l}\text { Литологически экранированный, } \\
\text { тектонически ограниченный }\end{array}$ & H+ \\
\hline
\end{tabular}

Рисунок 1 - Комплекс космогеологических методов поисков углеводородного сырья 
которой пойдет ниже. Собственно геодинамика и кинематика выражаются значками смещений по предполагаемым разломам и направлений тектонических напряжений.

Следующий шаг в работе с поверхностью Земли - анализ космических изображений с наилучшими для геологических целей техническими характеристиками. Критерии выбора снимков - единовременный охват больших территорий, достаточный набор каналов в разных частях видимого и теплового диапазонов, наилучшее разрешение в дальнем инфракрасном диапазоне, в котором вычисляются поле теплового излучения как среднее геоетрическое из летней и зимней безоблачных сцен, и относительная водонасыщенность как математическое отношение летней сцены к зимней. Этот параметр лучше, чем само поле излучения, выявляет геологические неоднородности, особенно в условиях резко континентального климата, когда разность летних и зимних температур максимальна. Именно таким климатом характеризуется территория Казахстана.

Важным элементом космогеологических исследований является работа с линеаментами. На основе исследований в каменистых пустынях (рисунок 2) линеаменты и их ансамбли классифицируются в ряд по времени возникновения от раннего диагенеза к литогенезу и, в финале - к тектоническим нарушениям [7]: 1) струйчатый аккумулятивный облик сухих долин; 2) однородная мелкоячеистая поверхность структурного известнякового плато; 3) полигонально-ячеистая сеть линеаментов, геометрически правильная сеть ортогональных и диагональных линеаментов; 4) преобладание концентрических элементов как признак депрессий; 5) преобладание радиальных элементов как признак антиклиналей; 6) ансамбли упорядоченных по направлениям, форме и размерам трещин с признаками стресса и смещений; 7) протяженные прямолинейные трещины в докембрийском основании.

И на поверхности, и на разрезах в инфракрасных изображениях различаются светлые и темные линеаменты. С первыми связываются зоны уплотнения и сухости, со вторыми - увлажненные трещиноватые разуплотненные зоны.

Третий шаг в изучении поверхности связан с использованием комбинаций из различных спектральных зон от видимых диапазонов до дальнего инфракрасного. По особенностям фотоизображения в различных каналах многозональных снимков можно судить об увлажненности грунтов, характере растительности и почв, и в некоторых случаях- о составе горных пород и строении недр. Наиболее благоприятны ландшафты каменистых пустынь, где растительный покров и почвы почти отсутствуют.

Представленный пример по Восточной пустыне Египта (рисунок 1, 2-й ряд свер$x y ;$ рисунки 3, 4) демонстрирует карту масштаба 1:250 000, и космический снимок Landsat-7 в использованной нами комбинации каналов 731 (средний инфракрасный, красный, синий). Более убедительных примеров удачного использования комбинаций каналов для геологического картографирования в публикациях мы не знаем, поскольку такую обнаженность, как в каменистой пустыне, на земной поверхности можно видеть только в карьерах. Оговоримся, что универсальных комбинаций каналов, пригодных для геологического дешифрирования в различных ландшафтах, не существует, и самая информативная из них подбирается путем совмещения снимков с наиболее надежными современными геологическими картами. 


\section{ГЕОЛОГИЯ}
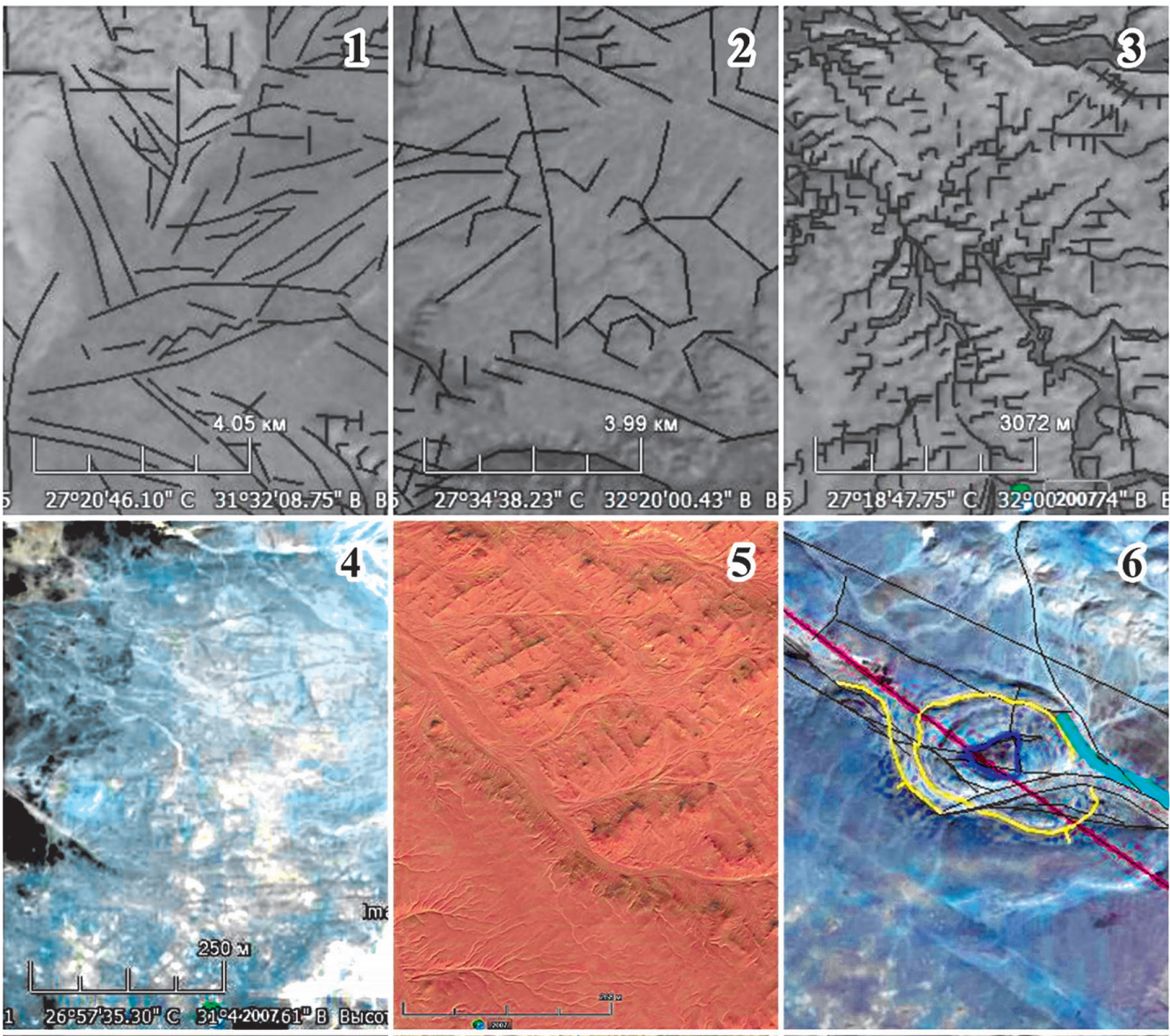

5
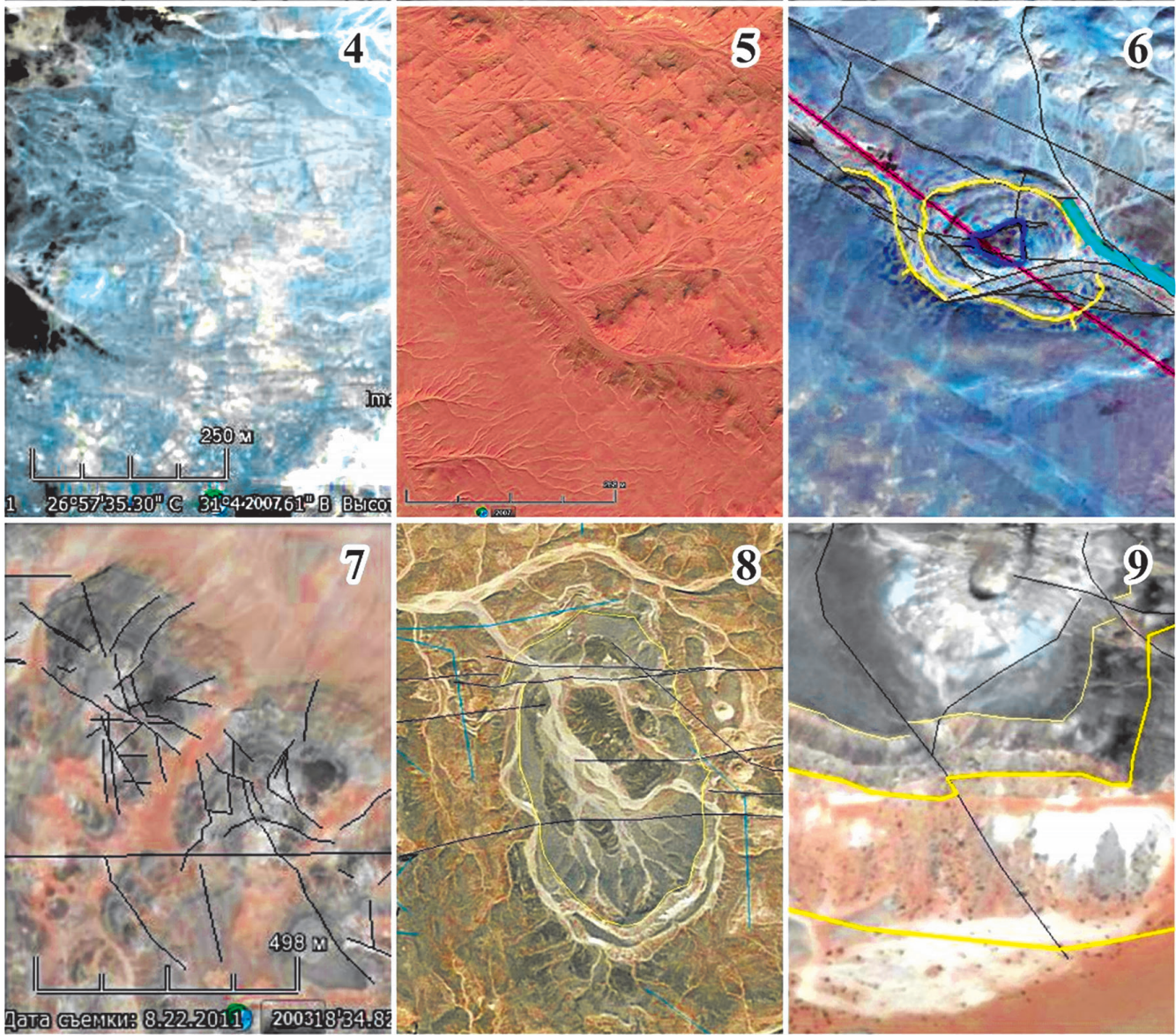

Рисунок 2 - Типовые ансамбли линеаментов в карбонатной плите Восточной пустыни Египта: 1 - вади; 2 - полигональная решетка; 3 - ортогональная решетка; 4 - скошенная ортогональная решетка; 5 - диагональная решетка; 6 - складка «птичий глаз»; 7 - выраженные в рельефе брахиантиклинали; 8 - выраженные в рельефе брахисинклинали; 9 - сдвиги и надвиги 
Синтезом данных предшественников и результатов дешифрирования космических снимков является космогеологическая карта, она отличается от стандартной отражением элементов слоистости и детальным отражением разломов и трещин. Мы считаем трещиноватость столь же важной характеристикой недр, как и возраст слоев, литология и складчатая структура.

Космогеологические карты демонстрируется в двух вариантах: в традиционных цветах согласно возрасту пород, и в индексах на фоне оптимальных комбинаций каналов Landsat. Иногда они практически совпадают, и обоснованность карты с очевидностью доказывается ее совмещением с естественными природными неоднородностями. Использование 3D образов поверхности из Google позволяет составлять космогеологические карты, местами даже более обоснованные, чем карты по результатам наземных съемок, поскольку замеры структурных элементов и толщин на космоснимках намного представительнее, чем разрозненные замеры в обнажениях. Космогеологическая карта - это внемасштабная основа, к которой в электронном виде должна быть привязана вся графика по исследуемому участку независимо от того, к поверхности она относится или к глубине. Именно от космогеологической карты мы прослеживаем структурные неоднородности на все большие и большие глубины методами тепловизионной генерализации исходного поля на поверхности земли, запечатленного на космических снимках в диапазоне TIR.

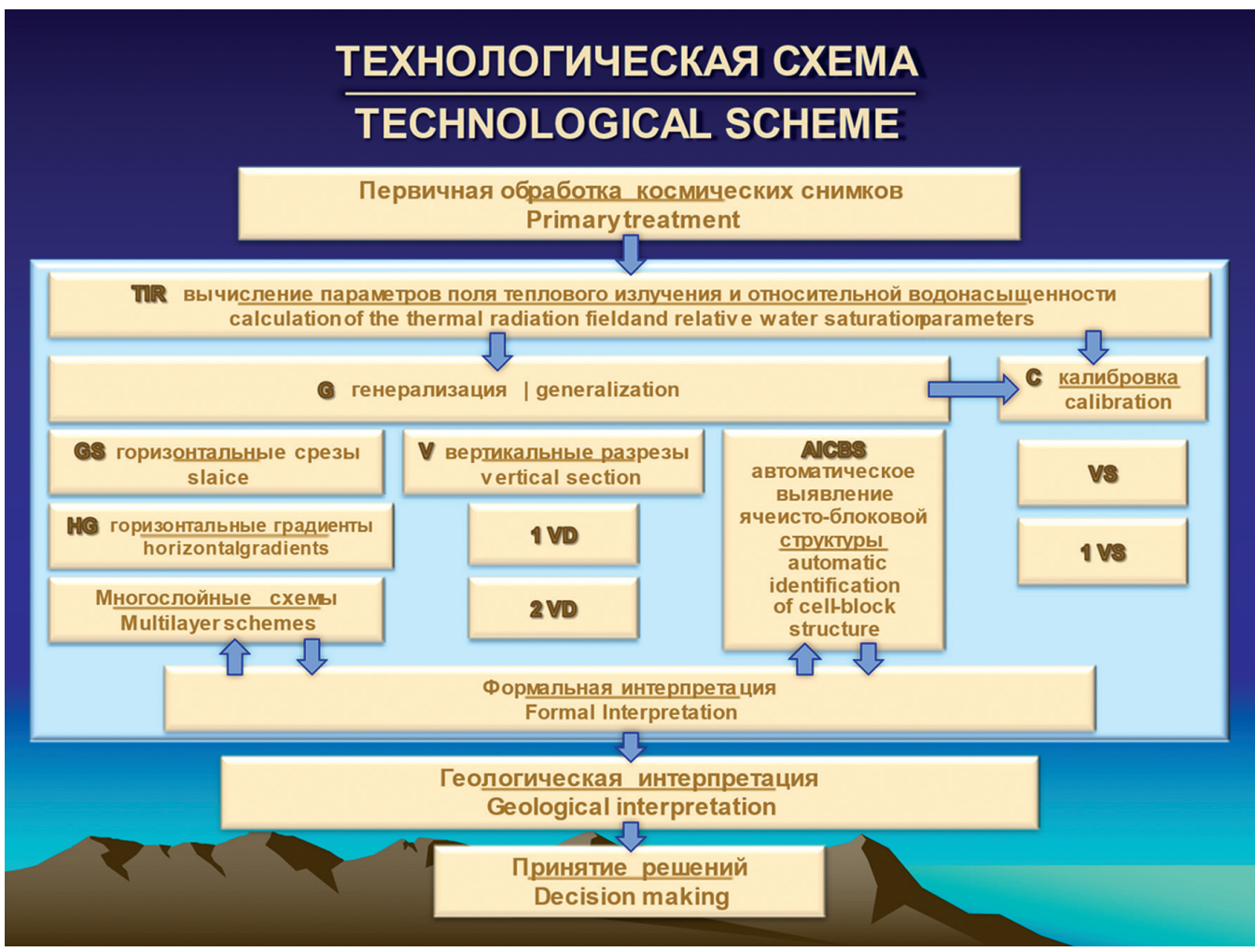

Рисунок 3 - Технологическая схема исследований космических снимков 


\section{ГЕОЛОГИЯ}

Методы тепловизионной генерализации - это способ математических преобразований исходных тепловизионных изображений в цифровые объемные модели поля теплового излучения и поля относительной водонасыщенности с целью выявления неоднородностей этих полей, отвечающих реальным геологическим неоднородностям в недрах [1-3]. Далее модель визуализируется по системе вертикальных разрезов по сетям $100 \times 100$ и $10 \times 10$ (обзорная стадия), и $1 \times 1$ км и детальнее (детализация), по субгоризонтальным разрезам через 60 м. При необходимости строится разрез по любому заданному сечению. Прослеживаются векторы тепла и холода, водонасыщенности и сухости, выделяются и классифицируются элементы слоистости и разломы, результаты дешифрирования «сшиваются» с космогеологической картой, с сейсмическими и буровыми разрезами, и таким образом получается объемная геолого-поисковая модель поисков полезных ископаемых на глубинах до 6 км, или глубже, в зависимости от разрешающей способности снимка в диапазоне TIR. Чем большую площадь отражает исходный пиксель, тем больше глубина проникновения, но детальность построений при этом, естественно, ниже.

Методики космогеологических поисков каждого полезного ископаемого осуществляются в соответствии со специально разработанными нами критериями.

\section{Поиски углеводородного сырья}

Используются как общеизвестные критерии поисков месторождений УГВ, так и разработанные нами, основанные на интерпретации цифровой модели поля теплового излучения и водонасыщенности:

1) расположение объектов под плоскостями геотермических несогласий, наибольших перестроек общего облика полей;

2) расположение объектов вблизи восходящих тепловых потоков;

3) наличие асимметричных «козырьков» на вертикальных разрезах поля теплового излучения в интервалах потенциально нефтегазоносных глубин;

4) ситуации встречного направления холодных сверху и нагретых снизу тепловых потоков;

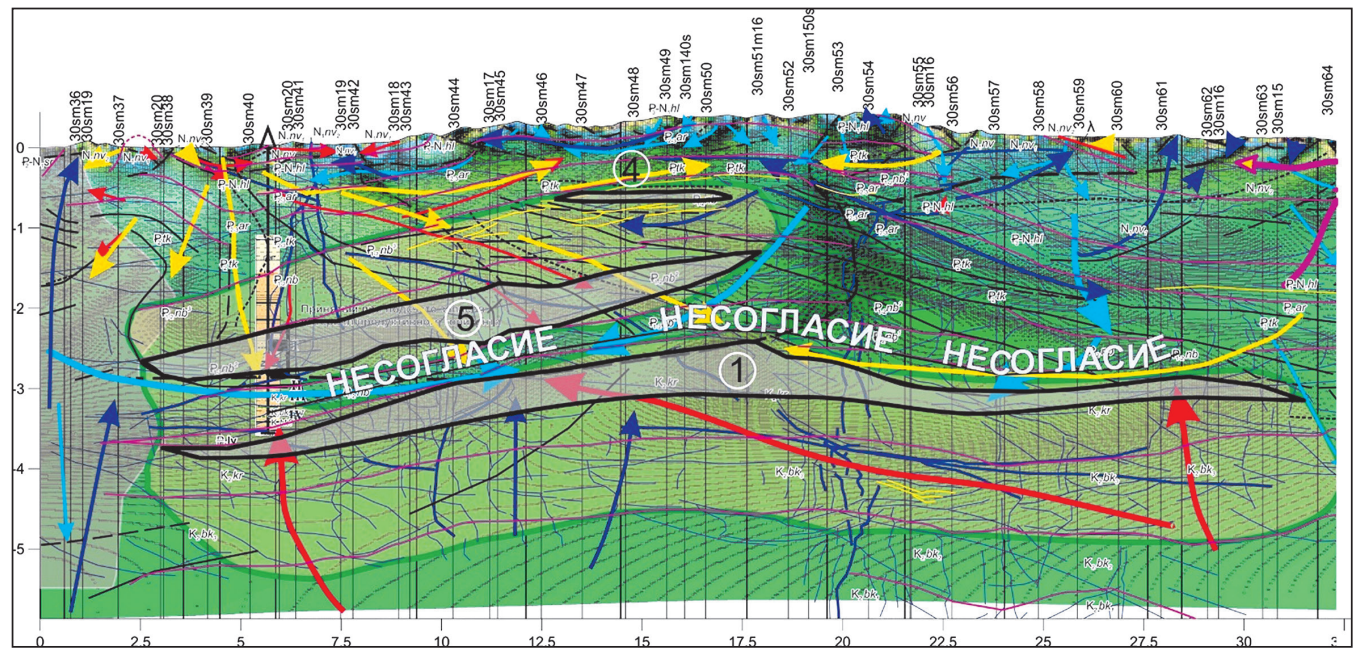

Рисунок 4 - Пример диагностики крупного флюидно-термодинамического несогласия 
5) на глубинах 1-3 км - соседство с геотермическими седловинами, штоками, террасами;

6) расположение объектов вне геотермических ям;

7) относительно более высокое гипсометрическое положение прогнозируемого объекта по отношению к окружающей геологической среде в рамках неких геологических ограничений - тектонических, литолого-стратиграфических, фациальных;

8) наличие косых восходящих струй повышенной водонасыщенности в интервале нескольких сот метров над предполагаемым или установленным объектом;

9) наличие глубоко проникающих векторов сухости в латеральных ограничениях объектов;

10) слабо проявленные восходящие векторы сухости непосредственно в объектах и над ними (на больших глубинах не различимы).

Поиски углеводородов могут выполняться как на очень больших слабо изученных площадях в несколько этапов (обзорный, основной, детализационный за 1-2 года), так и на конкретных участках с законсервированными и действующими скважинами - за 1 - 1,5 года. Затраты на предпроектные научные исследования на порядки меньше затрат на полевые работы, а вклад в конечный экономический результат может оказаться решающим. Приведем два примера из практики наших работ.

1. Блок Alam El Shawish (Египет), 2011 г., 974 км². Заказчик предоставил сейсмические разрезы 2D, и стратиграфические отбивки по 22 скважинам, и получил совершенно новые оценки перспектив как по разбуренной территории, так и по участку, по которому Заказчик приобрел материалы сейсморазведки уже после сдачи нашего отчета

Наши прогнозы были приняты и в отношении этажа еще не вскрытых тел под разрабатываемыми залежами, и в отношении объектов на не разбуренной площади. Об этом говорится в официальном отзыве на отчет и в совместной публикации Исполнителя работ и Заказчика [3]. Это первая в мире работа, в который доказана эффективность использования параметра относительной водонасыщенности недр даже под мощным покровом эоловых песков.

2. Законсервированное месторождение на Сахалине (Россия). 2018 г. 728 км². Изученность - несколько сейсмических разрезов, одно продуктивное пересечение нефтяной залежи в угленосной толще палеогена.

По результатам наших работ показана большая мощность найбутинской угленосной свиты палеогена, вмещаюшей залежь с утвержденными запасами нефти, и впервые обоснован ранее не прогнозировавшийся объект на более низком стратиграфическом уровне в ядре крупной складки под зоной тектонических срывов в морских эффузивно- терригенных отложениях красноярковской свиты мела с локализованными ресурсами порядка милиарда т нефти. Успех по данной площади настолько впечатляющий, что мы считаем целесообразным продемонстрировать часть итогового разреза, совмещенного с сейсмическим. В подложке - вторая производная поля относительной водонасыщенности (зеленый фон, изолинии) и теневой рисунок водонасыщенности по алгоритму AICBS. Стратиграфические границы 
показаны вишневым цветом, разломы и трещины - черным (линеаменты в полях излучения и водонасыщенности) и темнофиолетовым (линеаменты в сейсмическом рисунке). В зеленых контурах высветлены зоны, в которых наличие залежей не исключается, в жирных черных контурах - залежи с подсчитанными запасами (5) и ресурсами (4 - мелкий объект в палеогене, и 1 - гигантская залежь в красноярковской свите). Стрелки - это векторы: красные - тепла, синие - холода, желтые - сухости, фиолетовые - водонасыщенности. Срыв между объектами 5 и 1 и покрышка над объектом 1 диагностируется по протяженной зоне холода и на востоке - сухости, полному несогласию рисунка полей и встречной направленности векторов выше и ниже этой зоны. Разрез «сшит» с сейсмическими и тепловыми разрезами во всех прономерованных пересечениях.

Подтверждаемость прогнозирования крупных объектов с дебитами нефти более 50 м³ сут. по результатам работ на Куюмбинской площади в Сибири - 67-100\%, на скважинах с дебитами менее 50 м³/сут. - 43-57\%.

После проверки наших рекомендаций полевыми работами в Западной Пустыне Египта 8 авторов [8] известили: «Стратегия разведки для углеводородов, разрабатываемых ГП «Науканфтогаз», включены как традиционные, так и дистанционные методы зондирования (Туманов, Чебан, 2013), доказавшие свою эффективность».

\section{Поиски подземных вод}

Критерии космогеологических поисков подземных вод проверены работами по 4-м проектам: в Нагорном Карабахе, в Нигерии (штат Адамава) и в Мексике, в штатах Матеуала и Пьедрас Неграс:

1) благоприятное положение в общей гидрогеологической структуре;

2) достаточно большая площадь области питания;

3) сравнительная однородность водообильной части резервуара, выраженная на разрезах густым зеленым цветом, отсутствием или разреженным положением изолиний относительной водонасыщенности, темными тонами в структуре, автоматически построенной в алгоритме AICBS;

4) повышенные градиенты относительной водонасыщенности в окаймлениях водоносных гидрогеологических тел и соответствующих резервуаров;

5) разница в высотах над уровнем моря области питания и кровли водоносных гидрогеологических тел как гидравлическая предпосылка для самоизлива подземных вод по скважинам;

6) наличие водоупоров в кровле водоносных гидрогеологических тел как защита их от загрязнения и эвапорации.

Прогноз на воду требует скрупулезной интерпретации данных с построением сотен вспомогательных графических приложений. Ниже приводятся некоторые из них из отчета по исследованиям в штате Матеуала в Мексике. Облик и интерпретация объемной цифровой модели полей теплового излучения и водонасыщенности в артезианском бассейне Матеуала показаны на рисунке 1 (третий ряд рисунков сверху). 

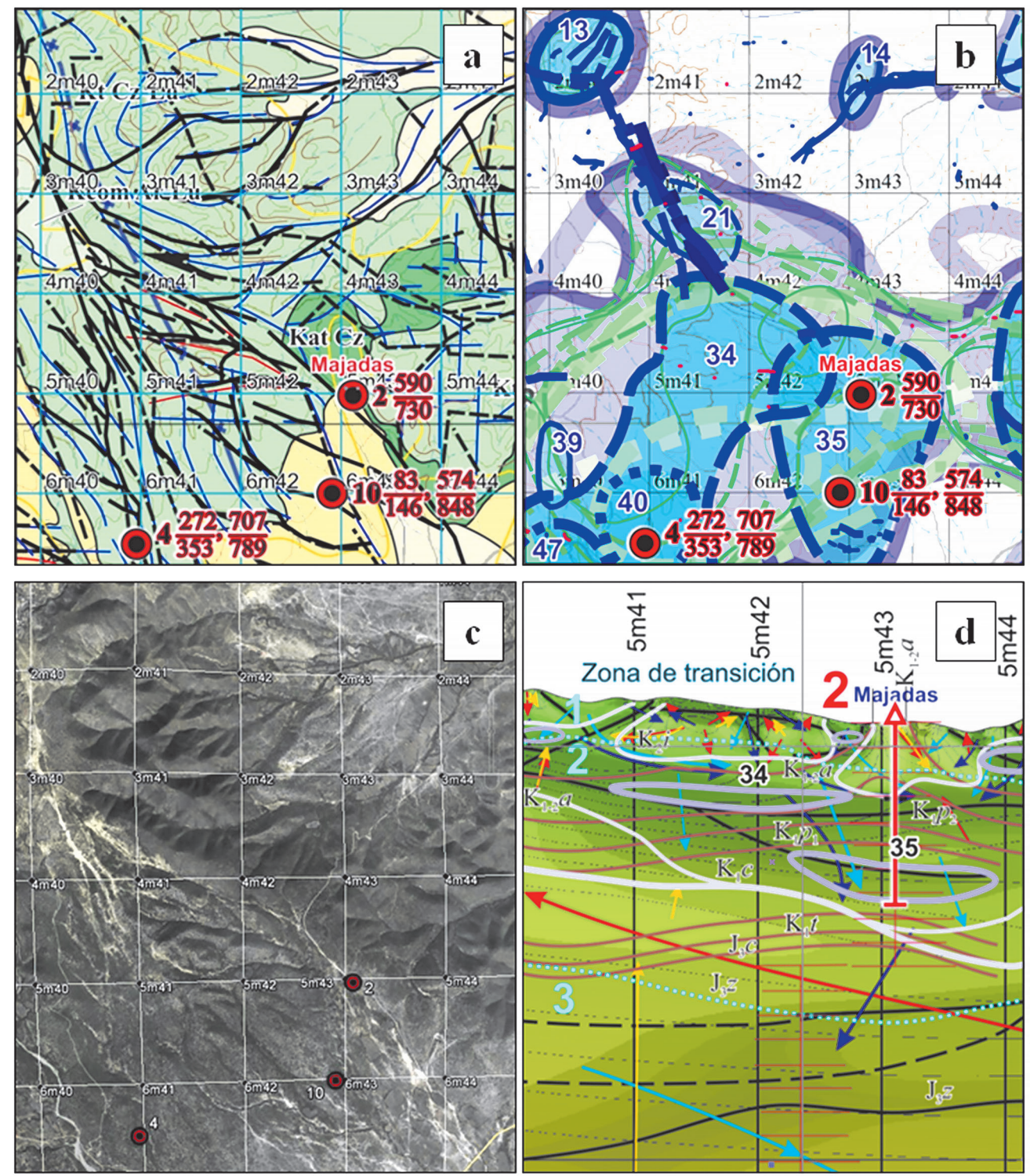

Рисунок 5 - Положение скважины Майадас в плане и в разрезе: а - на космогеологической карте; b - на карте прогнозов; $c$ - на снимках Google Earth; $d$ - на интерпретационном разрезе. На картах $a$ и $b$ у номеров рекомендованных скважин над чертой - глубина до кровли водоносных тел, под чертой - до их подошвы, на карте $b$ синие контуры - водоносные гидрогеологические тела на разных глубинах. На разрезе $d$ бледно-сиреневые и белые контуры - элементы гидрогеологического районирования, зеленый пунктир и цифры гидрогеологические этажи, черные цифры - номера прогнозируемых гидрогеологических тел. Стрелки-векторы: красные - тепла; синие - холода; фиолетовые - водонасыщенности, Разрезы (квадратная сеть с номерами) построены по сети 1×1 км. 


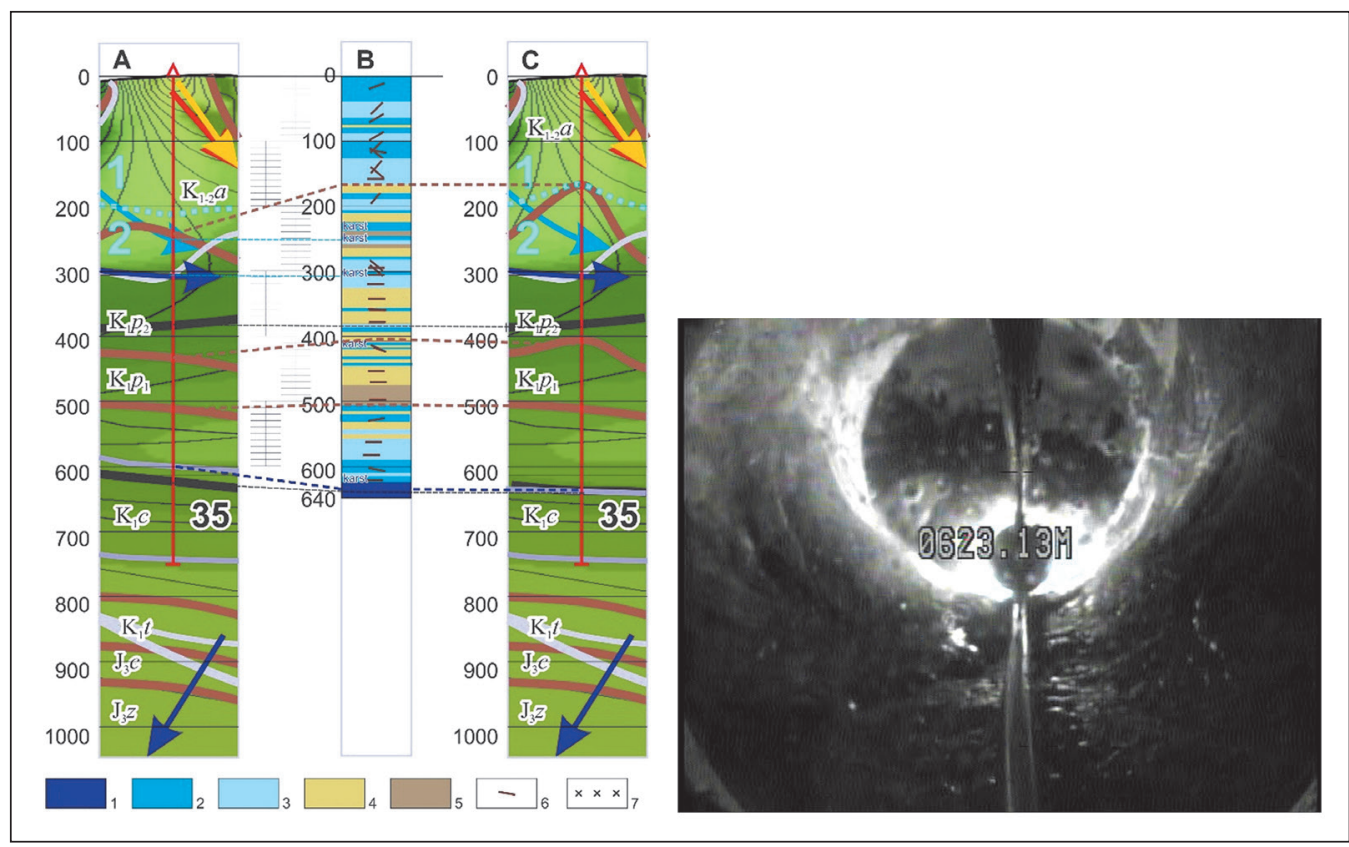

Рисунок 6 - Сопоставление прогнозируемого гидрогеологического разреза с видеозаписью ствола скважины Майадас: $A$ - прогнозируемый разрез до сопоставления с видеозаписью;

$B$ - интерпретация видеозаписи ствола скважины; $C$ - исправленный разрез с учетом интерпретации видеозаписи ствола скважины: 1 - вода; 2 - высокопроницаемые породы

(каверн больше 5\% объема пород); 3 - проницаемые (3-5\%); 4 - слабо проницаемые (1-3\%); 5 - весьма слабо проницаемые (пустоты мелкие, меньше 1\%); 6 - наклон слоистости; 7- дробленые породы

- Итоги сопоставления фотодокументации и наших прогнозов.

- Правильно предсказан характер залегания слоев, круто наклонный вверху и почти горизонтальный на глубинах более 300 м.

- Установлено совпадение карстовых полостей с векторами холода или повышенной водонасыщенности на глубинах 244 и 300м.

- В оси килевидной антиклинальной складки положение границы El Abra/Pena предсказано с ошибкой 68 м (29\%), ниже, в зоне субгоризонтального залегания пород, ошибки в предсказании положения границ Верхняя Рena/Нижняя Pena составила $4 \%$, а Нижняя Pena/Cupido - всего лишь $1 \%$ (!). Самая четкая литологическая неоднородность предсказана на глубине 500 м практически безошибочно.

- Верхняя граница водоносного гидрогеологического тела на глубине 623 м предсказана с ошибкой 4\%. Здесь следует иметь в виду, что космические съемки выполнены в 2003 г., а видеозапись стволы скважины - в 2014 г., и за это время уровень грунтовых вод мог понизиться.

\section{Поиски геотермальных источников энергии}

Отработанные нами площадки 1 и 2 находятся в Сальвадоре. Работы велись в 2007 г. на основе интерпретации поля теплового излучения.

Во всех геотермальных месторождениях обычны три гидрогеологические единицы: 
• верхний водоносный слой, обычно с гидрокарбонатно-кальциевыми слабо минерализованными, обогащенными кислородом водами, питающимися за счет атмосферных осадков;

- средний водоупорный горизонт со смешанным, существенно сульфатным составом вод;

- нижний водоносный слой - резервуар термальных вод и пара с существенно хлоридно-натриевого состава, газированными углекислотой, сероводородом, углеводородами.

На рисунке 7 показана разработанная нами типовая геодинамическая модель структуры поля теплового излучения в связи с источниками геотермальной энергии. Оптимальным представляется положение объекта поисков в ореоле фумарол и источников при их отсутствии непосредственно над геотермальным месторождением. Именно так расположены эти объекты по отношению к эпицентру геотермального поля Агуачапан [9].

Главные геотермические критерии поисков геотермальных источников энергии в вулканическом нагорье Сальвадора следующие: положительный восходящий тепловой поток, холодная покрышка над ним и, как следствие, повышенные вертикальные температурные градиенты в покрышке над резервуаром, субгоризонтально восходящее положение главного положительного вектора.

По литературным данным все термограммы имеют выпуклую форму по отношению к оси глубин, показывая интенсивное нарастание температуры в верхней зоне, обычно отвечающей водонепроницаемой толще. Температурный градиент в ней достигает величины 50-70 $\mathrm{C} / 100$ м. В обводненных породах температурный градиент резко уменьшается.

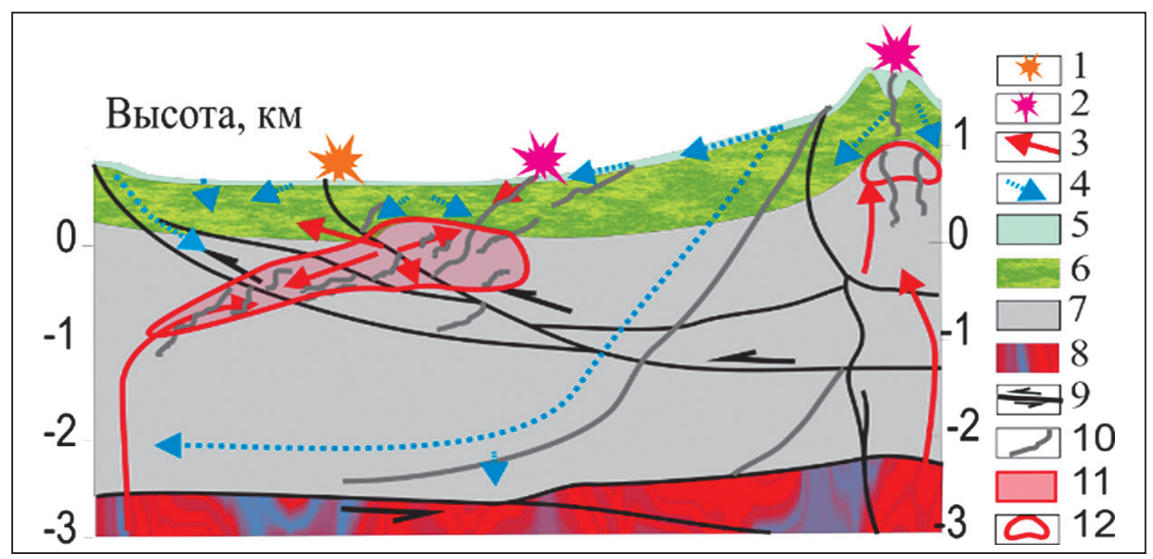

Рисунок 7 - Типовая геодинамическая модель структуры поля теплового излучения в связи с источниками геотермальной энергии: 1 - горячие источники; 2 - фумаролы; 3 - направления положительных векторов поля теплового излучения; 4 - направления отрицательных векторов поля теплового излучения; 5 - зона аэрации и пресных вод; 6 - водоупорный горизонт; 7 - резервуар; 8 - кристаллические метаморфизованные породы с рассолами;

9 - притертые экранирующие разрывные нарушения; 10 - приоткрытые проводящие разрывные нарушения; 11 - объекты с вероятным наличием пароводяной смеси; 12 - зоны с повышенным вертикальным температурным градиентом с вероятным преобладанием в составе флюидов неводных газов 
Если бы мы использовали в качестве поискового критерия положительные аномалии радиационной температуры, одним из наиболее перспективных был бы назван участок действующих вулканов с еще не остывший лавой. Однако водная составляющая магматических флюидов не образует здесь скоплений и свободно рассеивается в атмосферу. Более того, в составе газовой составляющей глубинных флюидов главная роль принадлежит здесь неводным газам. Такую же ситуацию мы ожидаем и под уже охлажденными вулканическими конусами, где температура флюидов в фумаролах на поверхности превышает $250^{\circ}$.

При конвективном механизме теплопереноса весьма вероятна прямая связь глубинных разогретых вод с тепловыми холмами и положительными векторами, а относительно холодных и пресных - с геотермическими ямами и отрицательными векторами.

Термобарометрические критерии. Сведения о барометрии в артезианских геотермических системах противоречивы.

Новозеландские исследователи [10] ввели понятие о термоартезианском давлении, связанном с температурой, сказывающейся в уменьшении объемного веса нагретой воды, благодаря чему возможна конвективная дифференциация вод, и за счет увеличения разуплотненного столба воды - разгрузка термальных вод на более высоких отметках, очевидно - в условиях повышенного пластового давления.

В тоже время известны геотермические поля, в которых пластовое давление в водоупорном горизонте и нижнем водоносном слое примерно на 15 бар ниже, чем расчетное для нормализованных условий [11].

Противоречие заключается в следующем. Артезианская система предполагает избыточное давление в резервуаре и повышение уровня вод в скважинах в соответствии с пьезометрическим уровнем. Фактически же наблюдается дефицит давления и соответствующее понижение статического уровня в закрытой системе резервуара, а также температуры ниже расчетных для насыщения пара. Это противоречие можно объяснить влиянием геодинамических факторов. Наличие замкнутого геологического пространства с дефицитом пластового давления в продуктивном резервуаре возможны в ядре и верхних частях растущих антиклинальных структур, а также в системах трещин, косо-поперечных к направлению главных тектонических напряжений и смещений в развивающемся надвиге. Именно к этому привел нас опыт исследований в Сальвадоре.

Поскольку Заказчик не предоставил нам разрезов по скважинам и обнажениям, отчетов по интерпретации геофизических данных, мы были вынуждены показать на разрезах не геологические тела, а термостратоны, по сути отвечающие геотермическим этажам, причем самый верхний из них как правило служит водоупором, под которым установлены либо прогнозируются объекты с перегретыми водами, а нижний из них предположительно отождествляется с кристаллическими породами фундамента, в данной местности - юрскими метаморфическими и магматическими породами.

В 2007 году мы еще не могли сопоставить положение тепловых потоков с относительной водонасыщенностью, поэтому с позиций сегодняшнего дня интерпретация и прогнозы могли бы значительно уточниться. Кроме того, по условиям контракта 
не предусматривался сбор и анализ гравитационных, магнитометрических, электроразведочных и других геофизических данных, использование которых также способствовало бы более глубокому пониманию геологии района. Тем не менее перспективными на картах прогнозов показано лишь около 12-15\% площадей, что почти на порядок сужает фронт полевых геологоразведочных работ и позволяет значительно снизить экономические риски.

В 2014 г. в процессе поисков подземных вод в Мексике мы уже прогнозировали положение не только векторов тепла и холода, но и водонасыщенности и сухости, и на этой основе выявили подземные восходящие водные потоки и рекомендовали участки для поисков теплых вод, представляющих интерес в отношении бальнеологии и курортологии (рисунок 8).

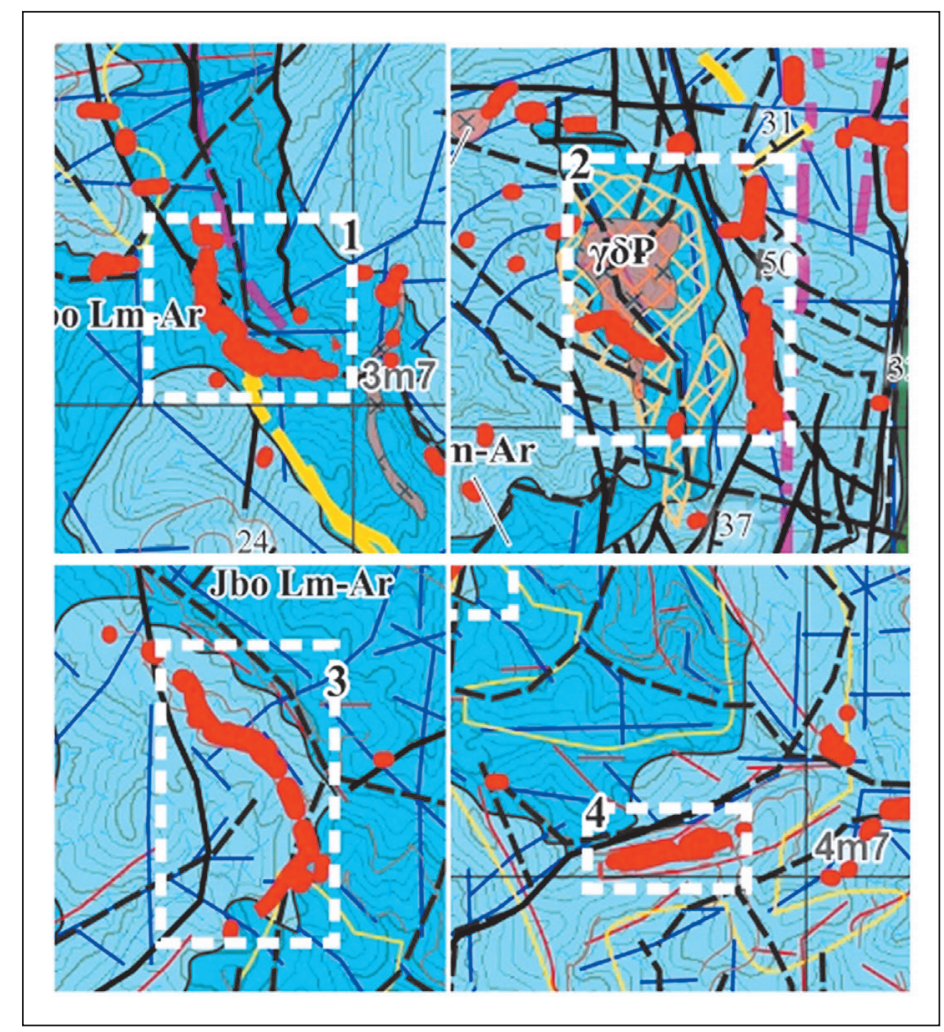

Рисунок 8 - Участки с линейными зонами тепла и влаги, рекомендованные к полевой заверке

\section{Поиски инфильтрационных месторождений урана}

Речь пойдет только о месторождениях типа несогласия. Возможность их обнаружения методом тепловизионной генерализации основывается на изучении материалов по бассейну Атабаска в Канаде. Мы сопоставили Line AA' gravity model [12] с нашей структурной моделью и убедились, что рудоконтролирующая зона, вмещающая гигантские месторождения McArtur.

River, Cigar Lake и др., отличается весьма своеобразными ансамблями тепловых и структурных элементов (рисунок 9). 


\section{ГЕОЛОГИЯ}

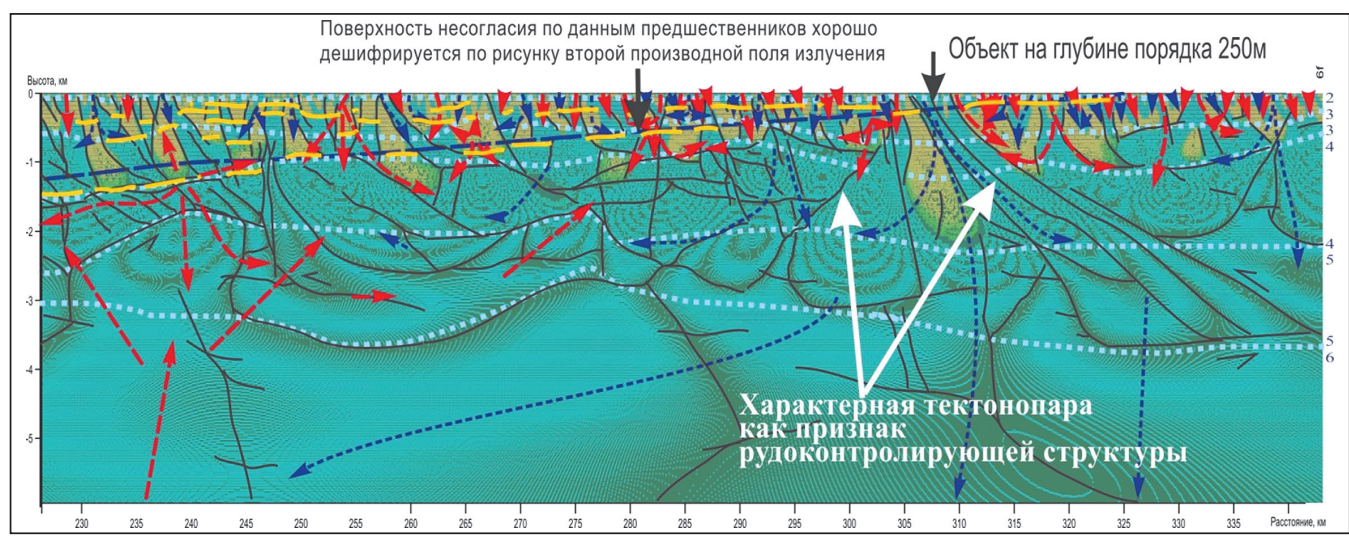

Рисунок 9 - Интерпретация разреза второй производной поля теплового излучения.

Векторы поля излучения показаны стрелками: красные - тепло; синие - холод;

черные линии - разломы; желтые - элементы слоистости

Тепловизионные признаки месторождений ранжированы нами по их важности [13]:

1) проявление структуры несогласия в поле теплового излучения в виде геотермической линии между этажами с различными размерами и стилем строения термических неоднородностей;

2) приуроченность современных конвективных термофлюидных потоков к зонам разломов, унаследованным от эпох рудообразования;

3) контрастная термодинамическая пара из наклонно нависающего разогретого козырька и подстилающего холодного потока;

4) характерный тектонический ансамбль, соответствующий рисунку теплового поля (круто наклоненный на запад разрыв в лежачем блоке и система пологих разрывов, наклоненных на восток, в висячем надвинутом блоке.

Термогеодинамические предпосылки поисков месторождений урана типа несогласия сопоставимы с традиционными геофизическими, в частности - с магнитометрическими и сейсмическими, а по наглядности и дешевизне не уступают им. Но еще раз подчеркнем - прежде чем планировать дорогостоящие полевые работы, более того - прежде чем определиться с лицензированием права на эти работы, чтобы снизить экономические риски, необходимо произвести целевую интерпретацию космогеологических данных.

\section{Поиски месторождений алмазов}

Тепловизионной предпосылкой для поисков кимберлитов (ультраосновных пород) как вместилища алмазов по тепловому каналу является их аномально высокая яркость в 6-м канале Landsat-7. Библиотека спектров излучения природных объектов опубликована на сайте [14]. Примечательны очень низкая яркость в SWIR и VNIR и относительно большие коэффициенты спектральной яркости в диапазоне TIR). Сопоставимая яркость в 6-м канале - только у гетита, однако по размерам и форме выявленные нами в штате Адамава в Нигерии фотообъекты скорее отвечают кимберлитовым трубкам взрыва. Одно из прогнозируемых нами кимберлитовых полей показано на рисунке 10. 


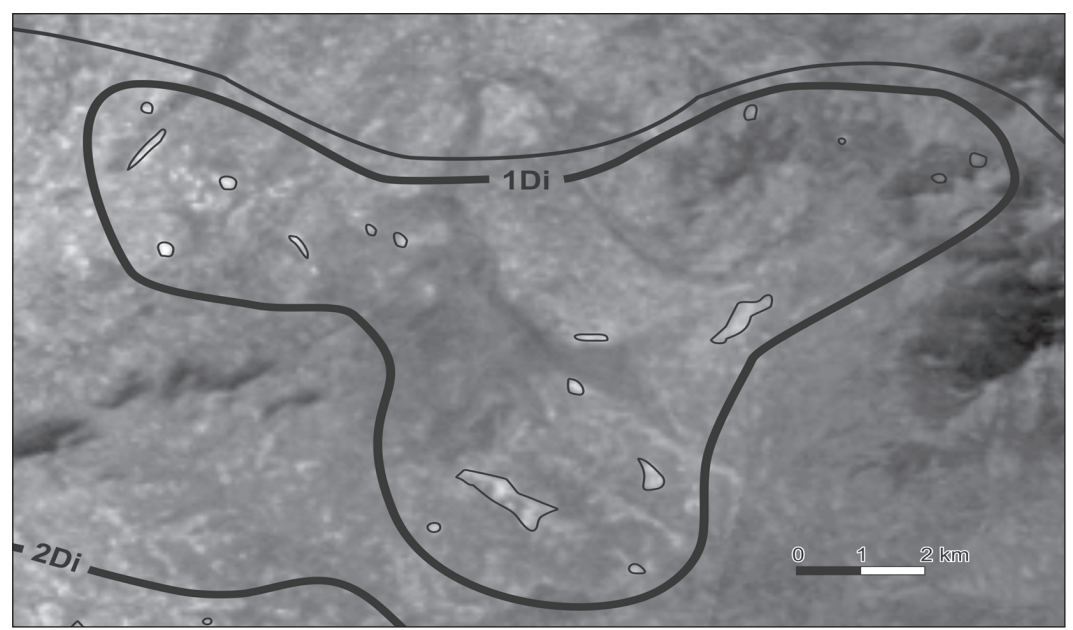

Рисунок 10 - Потенциально кимберлитовое поле в Нигерии.

Космический снимок Ladsat 7, слева -в канале TIR, справа в комбинации каналов B4/B3. Светлым аномалиям на снимке слева отвечают темные на снимке справа

Для комплексной оценки бассейнов водотоков, дренирующих потенциально алмазоносную по космогеологическим признакам область, рекомендуется отбор и промывка двух намеченных нами валовых шлиховых проб объемом $50 \mathrm{~m}^{3}$ каждая. Таким образом может быть получена информация о наличии в аллювии не только алмазов и их спутников, но и о количествах золота, полудрагоценных камней, минералов тантала, ниобия, титана, циркония и др. При получении положительных результатов необходимо провести шлиховые поиски по сети водотоков и элювию выявленных аномальных объектов.

\section{Поиски полиметаллических руд}

При работах в Нигерии мы столкнулись с феноменом, когда совпадают направленные от поверхности векторы сухости и холода. Обычно векторы холода совпадают с векторами водонасыщенности. Сухость обуславливает молекулярный (кондуктивный) механизм теплопереноса, а четкая локализация вектора в узкой зоне - наличие какого-то плотного тела с высокой теплопроводностью, либо соляного, либо рудного. Данных по детальной гравиметрии у нас не было, и мы высказали предположение, что объекты такого облика представляют собой рудные тела, поскольку в трех точках на участке были известны образцы с баритом и галенитом из элювия, но структура участка была неизвестна. Мы тщательнейшим образом отдешифрировали космические снимки, построили разрезы, и пришли к выводу, что главное тело крутопадающее, в южной своей части - полого падающее на юго-запад. Тело прослеживается от поверхности до глубины 270 м. Длина объекта поисков 1700 м. Такое протяженное тело может представлять собой крупное месторождение. Для вскрытия объекта необходимо пробурить пять наклонных скважин, объемом бурения 890 м (рисунки 11, 12).

Таких объектов в изученной части Нигерии - многие десятки, и вести наземные поиски барит-полиметаллических руд без учета результатов космогеологических исследований - экономически нецелесообразно. 


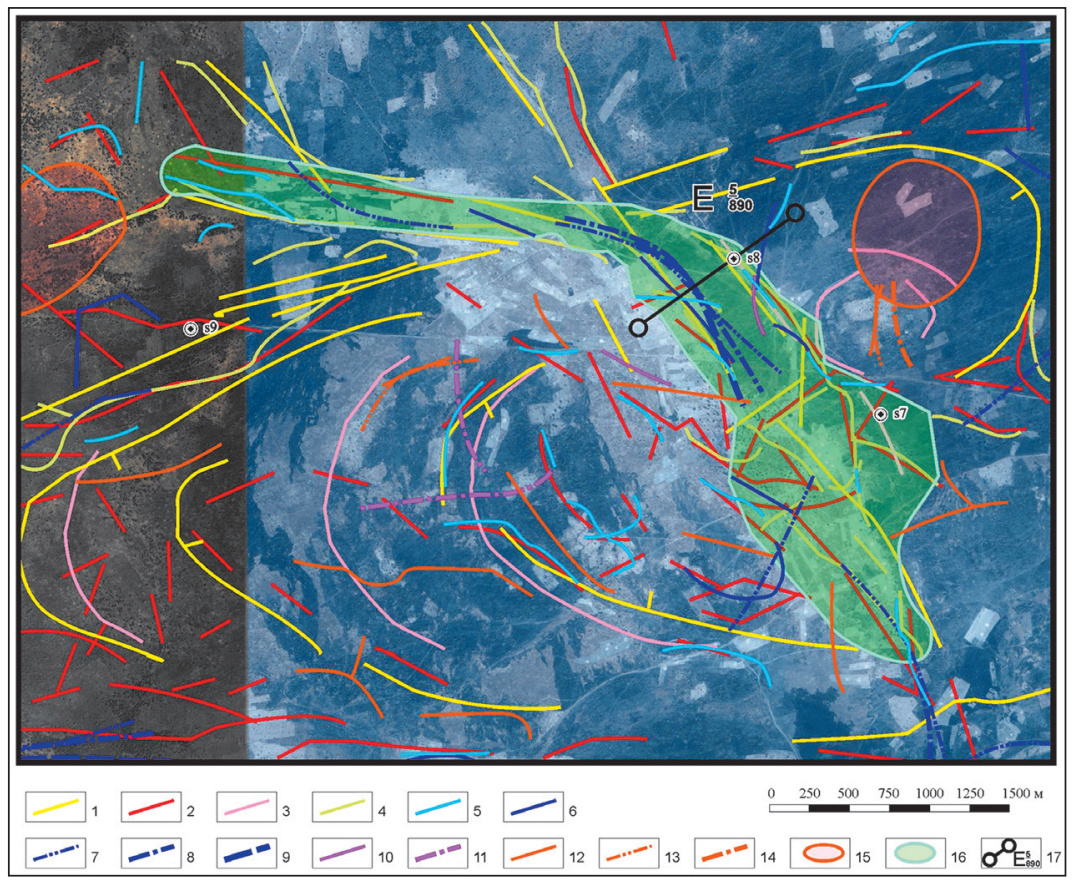

Рисунок 11 - Объемная модель структуры участка барит-галенитовой минерализации:

1 - линеаменты по снимку Ландсат в видимом диапазоне; 2 - линеаменты по снимку в тепловом диапазоне; 3 - линеаменты по снимку из Google; 4 - линеаменты по полю теплового

излучения на глубине 30 м; 5 - конвективные холодные линеаменты на глубине 30 м; кондуктивные холодные линеаменты на глубинах: 6-90 м; 7-150 м; 8-210 м; 9-270 м;

кондуктивные теплые линеаменты на глубинах: 10 - 90 м; 11 - 210 м; конвективные теплые линеаменты на глубинах: 12 - 90 м; 13-150 м; 14-210 м; 15- участки конвективно разогретые;

16 - участки кондуктивно охлажденные; 17 - линия скважин, ее индекс, над чертой количество скважин, под чертой - объем бурения. В подложке - изображение из Google.

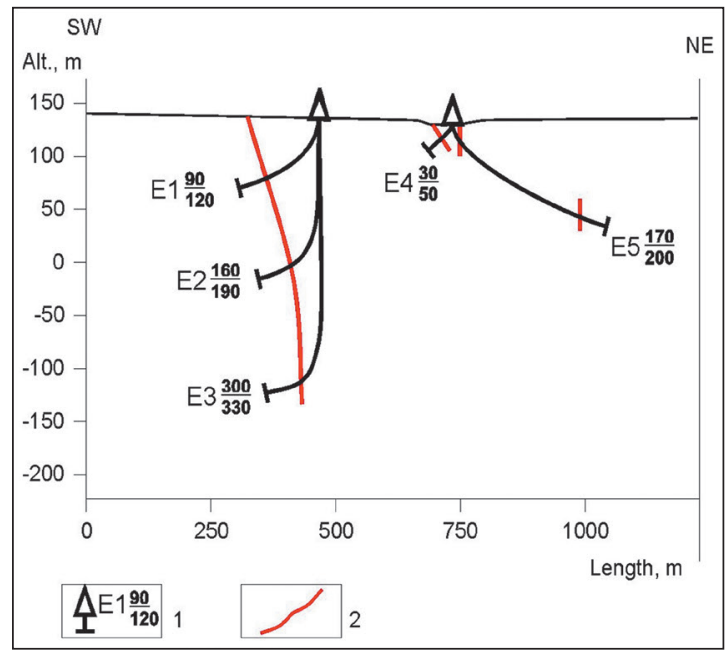

Рисунок 12 - Ожидаемый разрез рудной зоны и положение рекомендованных скважин:

1 - рекомендуемые скважины, номер, над чертой глубина до кровли объекта, под чертой длина проходки; 2 - холодное кондуктивное тело (рудная зона) 


\section{Выводы}

Космогеологические методы поисков не заменяют традиционные методы поисков и, тем более, разведки полезных ископаемых, но предохраняют от неоправданных экономических рисков на этапе выбора объектов для инвестиций. По природным особенностям и по степени геологической изученности широкое применение космогеологических методов особенно актуально на территории республики Казахстан.

Преимущества космогеологических методов:

- равномерность сети наблюдения;

- геометризация объектов прогнозирования;

- экологическая безупречность;

- планирование дорогостоящих работ только там, где они действительно необходимы;

• оптимальное соотношение показателей цена- время-площадь территорий.

\section{ЛИТЕРАТУРА}

1 Мухамедяров Р.Д. Метод видеотепловизионной генерализации его аэрокосмическое аппаратурное оснащение // Интервал. - 200. - № 29 (44). - С. 59 - 62. [Muhamedyarov R.D. Metod videoteplovizionnoj generalizacii ego aerokosmicheskoe apparaturnoe osnashchenie // Interval. - 200. - № 29 (44). - S. 59 - 62.]

2 Мухамедяров Р.Д Метод видеотепловизионной генерализации и его прикладное значении. Пятые научные чтения памяти Ю.П. Булашевича, 2009. - C. 28-43 http:// igfuroran.ru/bulash2009/311-378.pdf [Muhamedyarov R.D Metod videoteplovizionnoj generalizacii i ego prikladnoe znachenii. Pyatye nauchnye chteniya pamyati YU.P. Bulashevicha, 2009. - S. 28-43 http://igfuroran.ru/bulash2009/311-378.pdf]

3 Туманов В.Р., Мухамедяров Р.Д. Метод видеотепловизионной генерализации - одно из перспективных направлений исследований геологии углеводородов // Повышение нефтеотдачи пластов на поздней стадии разработки месторождений и комплексное освоение высоковязких нефтей и природных битумов». - Казань: «Фэн», 2007. - С. 580-585. [Tumanov V.R., Muhamedyarov R.D. Metod videoteplovizionnoj generalizacii - odno iz perspektivnyh napravlenij issledovanij geologii uglevodorodov // Povyshenie nefteotdachi plastov na pozdnej stadii razrabotki mestorozhdenij i kompleksnoe osvoenie vysokovyazkih neftej i prirodnyh bitumov». - Kazan': «Fen», 2007. - S. 580-585.]

4 Tumanov V.R., Cheban V.D. The application of the thermal imaging generalization method for hydrocarbon accumulation evaluation in the Western Desert of Egypt. http://www. naftogaz.com/files/journal/3a_2013_preview.pdf

5 Туманов В.Р. Предполевой комплекс космогеологических методов поисков углеводородного сырья // Материалы XXII Международной конференции (Школы) по морской геологии. - Москва, 2017. - Т. 2. - С. 237-242. [Tumanov V.R. Predpolevoj kompleks kosmogeologicheskih metodov poiskov uglevodorodnogo syr'ya // Materialy XXII Mezhdunarodnoj konferencii (SHkoly) po morskoj geologii. - Moskva, 2017. - T. 2. - S. 237-242]

6 Дабаев А.И., Мухамедяров Р.Д., Туманов В.Р. Метод видеотепловизионной генерализации и его геолого-геофизическое значение // Нефть и газ. - 2011. - № 2(62). - C. 39-48. [Dabaev A.I., Muhamedyarov R.D., Tumanov V.R. Metod videoteplovizionnoj generalizacii i ego geologo-geofizicheskoe znachenie // Neft' i gaz. - 2011. - № 2(62). - C. 39-48.]

7 Туманов В.Р. Линеаменты и локальные складки в эоцене Северо-Восточной Пустыни Египта, их соотношение с литогенезом. // Материалы XXII Международной 
конференции (Школы) по морской геологии. - Москва, 2017. -Т. 5. - С. 357-361. [Tumanov V.R. Lineamenty i lokal'nye skladki v eocene Severo-Vostochnoj Pustyni Egipta, ih sootnoshenie s litogenezom. // Materialy XXII Mezhdunarodnoj konferencii (SHkoly) po morskoj geologii. - Moskva, 2017. -T. 5. - S. 357-361.]

8 Kitchka A.A.,. Arkhipova S.L, Bezkhyzhko O.M., Kuzmenko P.M., Makeev V.V., Shevchenko O.A., Bashkirov G.L., Vakarchuk S.G. Tectonisedimentary evolution of the Abu Gharadig basin and exploration challenges for the Western Desert province, Egypt / XIVth International Conference - Geoinformatics: Theoretical and Applied Aspects 11-14 May 2015, Kiev, Ukraine.

9 Laky C., Lippmann M.J., Bodvarsson G.S., Retanat M., Cuellart G. Hydrogeologic model of the Ahuachapan Geothermal Field, El Salvador. 1989. (https://escholarship.org/uc/ item/67s9n824)

10 Белоусов В.И., Белоусова С.П. Природные катастрофы и экологические риски геотермальной энергетики. - Петропавловск-Камчатский: КГПУ, 2002. [Belousov V.I., Belousova S.P. Prirodnye katastrofy i ekologicheskie riski geotermal'noj energetiki. - Petropavlovsk-Kamchatskij: KGPU, 2002.]

11 Proceedings, Fourteenth Workshop on Geothermal Reservoir Engineering Stanford University, Stanford, California, January 24-26, 1989.

12 Exploration for Unconformity Uranium Deposits in Western Canada, R. Matthews, R. Koch, M. Leppin, p.995, figure 4 (http://www.exploration07.com/pdfs/Expl97/12_03 pdf)

13 Туманов В.Р., Мухамедяров Р.Р. Поиски месторождений углеводородного сырья, урана, геотермальных источников энергии методом видеотепловизионной генерализации. /Доклад на 8-м Петербургском Международном Форуме ТЭК. 2008. http://www. space geo.ru [Tumanov V.R., Muhamedyarov R.R. Poiski mestorozhdenij uglevodorodnogo syr'ya, urana, geotermal'nyh istochnikov energii metodom videoteplovizionnoj generalizacii. /Doklad na 8-m Peterburgskom Mezhdunarodnom Forume TEK. 2008. http://www.space geo.ru]

14 NASA JPL HOME CALIFORNIA INSTITUTE OF TECHNOLOGY http://speclib.jpl.nasa. gov/search-1/resultsdisplay3 